\title{
A Descriptive Study on Corrective Feedback and Learners' Uptake during Interactions in a Communicative EFL Class
}

\author{
Parvin Safari \\ Iranian Schools, Kuwait
}

\begin{abstract}
The current observational and descriptive study makes an attempt to present the interactional discourse patterns of corrective feedback (CF) and uptake occuring in a communicative adolescent EFL class. Using Lyster and Ranta's corrective discourse model (1997), this study intends to investigate, describe, and analyze the discourse patterns of corrective feedback utilized by an Iranian teacher and also their relationship to the learner's uptake and the repair of those errors. Transcripts totaling 16 hours of classroom interaction included 181 episodes, each containing a trigger (error) produced by the learner, a CF move from the teacher and a learner's subsequent uptake in response to the CF. The findings obtained from such context reveal the ratio and distribution of the six different feedback types as well as those of different kinds of learner's uptake and immediate repair of errors.
\end{abstract}

Index Terms - corrective feedback, uptake, immediate repair, Lyster \& Ranta's corrective discourse model

\section{INTRODUCTION}

Taking a look at the field of second language acquisition, we can see that the interaction has been the focus of many studies. Inside this field, different views regarding the role of classroom interaction and discourse can be seen mainly with a focus on either teachers or learners, and their speech separately or interactively (Surakka, 2007). When it comes to second or foreign language learning, the most significant issue that attracts our attention is language and how it is appropriately dealt with in interaction occurring between teacher and students. In this regard, one of the areas in the context of language learning and discourse which has been closely taken into account, examined or studied is corrective feedback. The significance of corrective feedback (CF) can be found through the observation of the speech events in the form of moves taking place during communicative-based foreign language lessons and in how these moves play significant roles in learners' developing language. It is now accepted that errors play a crucial role in language learning but the way through which they are handled in order to lead to the maximum benefit is also significant. Through the use of feedback moves, teachers can suitably cope with the errors occurring in discourse events. Accordingly, this study intends to explore the discourse patterns of CF and learner's uptake in a communicative Iranian context. So, at first, it makes an attempt to present an overview of reception and production theories of language acquisition, a review of corrective feedback studies, and then it describes what happens in the respective context with regard to the interactively constructed moves between a teacher and students.

\section{LITERATURE REVIEW}

\section{A. A Brief Review of Language Acquisition Theories of Reception and Production}

Over the past few years, there has been serious attention on the part of second language acquisition (SLA) researchers toward the crucial role of interaction in language learning and its contribution to generate plentiful opportunities for second language acquisition via the negotiation of linguistic input taking place between learners and interlocutor. A growing interest in interaction and its role in language acquisition appeared due to the reaction toward Comprehensible Input theory (Krashen, 1985). Based on Input theory, learners move from their current competency level (i) to the pursuing level (i+1) via comprehending input containing (i+1). Accordingly, when learners understand input containing structures which are slightly beyond their current competency level, acquisition takes place. Krashen believes that structures slightly above the learners' existing competency level are understood by learners through the use of context, the world knowledge together with the current competence. In sum, based on Krashen's view, there are two ways by which comprehension of input is facilitated: simplified input by the teacher and the learner's use of context.

However, on different grounds, Krashen's theory was criticized by several people. Criticisms targeted at the way of constructing the theory and the kind of evidence used to support it. For instance, based on Larsen-Freeman and Long (1991), it is classified as a nativist theory on account of the fact that the explanation of language acquisition is on the basis of a genetically based language acquisition device. Larsen-Freeman and Long also believed that while testability is a condition for every hypothesis, this is not met for the statements in this theory due to its unfalsifiability and its 
untestable parts. Moreover, respective theory could not be empirically proved and it partly described processes involved in second language acquisition.

Another criticism was related to the fact that although the comprehensible input constituted a necessary condition, it was not sufficient for SLA. Some researchers (e.g. Doughty \& William, 1988) found that certain linguistic features failed to emerge, in spite of years of meaningful input. This actually inspired Focus on Form (FonF), a term coined by Long (1991). In Long's words, the input which is shaped via interaction contributed strongly and directly to the acquisition and that in order to make input comprehensible, modifications and adjustments are needed for the interactional structure of conversation.

In deed, in second language acquisition research, it is now generally accepted that for learners to fluently and accurately speak a foreign language, there is a need to practice it through speaking due to this fact that comprehensible input (CI) is essential but not sufficient for language acquisition. Comprehensible Output Hypothesis suggested by Swain $(1985,1995)$ actually reflects the inadequacy of Input Hypothesis with an emphasis on "comprehensible output" and" pushed language use". To negotiate meaning which is accurate, appropriate, and coherent, learners are persuaded to produce output which is vital to develop their accuracy.

Therefore, it was argued that the output as a crucial component is necessary for learners in order to achieve successful language acquisition. Actually, this argument that the output as a crucial condition for second language learning was originally on the basis of observing the immersion programs taking place in Canada. In Swain's words $(1985,1995)$, it was hypothesized that the immersion classrooms suffered from the lack of the opportunities for the use of language. She also believed that the production of language moved learners from a semantic level in the use of language to a syntactic use. According to Swain (1995, p.128), "Output may stimulate learners to move from the semantic, open-ended nondeterministic, strategic processing prevalent in comprehension to the complete grammatical processing needed for accurate production. Output, thus, would seem to have a potentially significant role in the development of syntax and morphology."

Accordingly, it is understood that through the opportunities for negotiation and production, learners are able to receive feedback. In fact, when given the chances of producing language, learners are forced to consider syntax in their own speech. In other words, in order to be fully understood in the second language, learners are required to be pushed in the production of language and may try out new structures or modify their own speech. Swain refers to this as "pushed language use". According to Swain $(1985,1995)$, through producing the language, learners might consciously recognize some of their linguistic problems. Moreover, she holds that output gives this chance to learners so as to test their hypotheses by making a comparison between their own production with the correct input and then to formulate correct L2 representations. Interaction Hypothesis (Long, 1983) is closely linked to Output Hypothesis (Swain, 1985) with great emphasis on the grammatical forms embedded in the context of communicative tasks and activities. According to Mackey (1997), this hypothesis actually evolved from Hatch's work (1978) on the significance of conversation to developing grammar and from Krashens' claims (1985) that comprehensible input is a necessary condition for SLA.

Inspired by Krashen's input hypothesis, this reception-based theory considers the significance of comprehensible input in the form of conversational modifications and the important role of interaction occurring in two-way communication. With respect to the importance of interaction and its role in language learning, Long (1983) argues that acquisition is more facilitated through interaction due to the linguistic and interactional adjustments that take place in the communicative discourse of language classroom so that it provides the necessary input which is needed for learners to negotiate for meaning while communication breakdowns occur. In the course of negotiation, learners modify and restructure their interaction to reach mutual comprehension. Through the result of interaction and negotiation, learners have more access to corrective feedback on their own productions in order to understand and use language that is incomprehensible. It means that successful language learning relies on the amount of adjustments made by the interactants in order to understand each other and these attempts to make input comprehensible.

Furthermore, the Output Hypothesis and Interaction Hypothesis are primarily concerned with form focused instruction or focus on form within the communicative context. In Long and Robinson's terms (1998), through the provision of negative feedback during meaning-based interaction, attention is shifted to linguistic forms triggered via the problems concerning comprehension or production. During these episodes of communicative breakdowns, learners become aware of certain differences between their current level of language or interlanguage (IL) and the target language (TL), that according to Schmidt and Frota (1986), it is called noticing the gap. Schmit (1990, 1995, 2001) argues that in order for learners to develop L2 acquisition, such noticing or conscious awareness is essential. She suggests that what is noticed in input becomes what is known as intake for second language learning. Schmit and Frota (1986) have also emphasized that learning enhancement occurs when, through 'noticing the gap', language learners become aware of the discrepancy existing between the input and their interlanguage. Whereas it is not obvious that this type of noticing is triggered by formal instruction (Lightbown, 2000), findings gained from form - focused instruction indicate that those students who were formally instructed usually outperformed those who were taught language by meaning-focused instruction. Furthermore, pushed output enjoys a crucial role in form-focused instruction so that this type of pushed output enriches language learners' linguistic accuracy via requiring them to generate the language which is precise, coherent and appropriate. 
It is worth mentioning that some distinctions in SLA literature are the by products of form- focused instruction. For instance, the difference between two types of focus on form, that is to say, incidental and planned focus on form (Ellis, 2001, 2005). Based on the definition of incidental focus on form, it is understood that the linguistic items addressed as they occur spontaneously within the meaning-focused activities, have not explicitly selected for teaching. The aim is to elicit general samples of the language rather than specific forms (Ellis, Basturkman \& Loewen, 2002). In contrast, planned focus on form instruction is intentionally the outcome of previous planning on the part of the teacher. Actually, it consists of previously selecting the targeted grammatical forms within a meaning-focused activity, either in the form of input or output. The respective form-focused instruction is extensive and frequently targets the same linguistic structure (Ellis, 2001a).

In the literature of SLA, another distinction can also be made between two sorts of focus on form: reactive and preemptive (proactive) focus on form (Long \& Robinson, 1998). A reactive approach is also called error correction, corrective feedback, or negative evidence/feedback (Long, 1996). Reactive focus on form can be defined when something is said erroneously and then the error is corrected by the teacher or another student. In other words, it can be said that it refers to the use of corrective feedback by the teacher during interactively communicative based activities as well as other teachers' efforts to draw learners' attention to linguistic features while opportunities for the use of corrective feedback arise in the context of meaning focused activities. Thus, corrective feedback can be supplied through this type of focus on form. Accordingly, teachers are required to have high skills to notice the error, analyze it and provide learners with the appropriate feedback and this is all done in a natural and spontaneous way (Doughty \& William, 1998; Lightbown \& Spada, 1990; Lyster, 1998a, c, p.67). With regard to the respective definition, error is considered as the trigger leading to the interactional discourse targeting a linguistic feature (Ellis, et al., 2001b).

Preemptive focus on form (Long \& Robinson, 1998) in contrast with reactive incidental focus on form, which has received relatively considerable attention from resea

rchers, has been largely ignored. As the name suggests, preemptive focus on form is the teacher's or a learner's attempts to begin explicit attention to a linguistic feature so as to avoid the occurrence of an error, although no real difficulty in speaking is arisen (Ellis, 2001b, p.414). With respect to the different kinds of distinctions, in this research study, reactive incidental focus on form in teacher-student interaction is taken into account.

\section{B. A Review of Corrective Feedback Studies}

An increasing number of SLA studies on the provision and use of oral feedback has consistently shown that feedback can enhance noticing, acquisition and retention of language forms (Iwashita, 2003; Leeman, 2003; Macky, 1999; Mackey \& Philip, 1998; Oliver \& Mackey, 2003; Philip, 2003). The contribution of Corrective feedback can be witnessed in assigning the chances to the learners in order to adjust their output, push them to notice the gaps in their interlanguage (McDonugh, 2005). However, it is essential to know that studies conducted in immersion classrooms have shown that whether learners are capable of modifying their output may rely on the feedback sort provided and that the sorts of feedback that increase learners' modified output may relatively rarely occur in the context of language classrooms (Lyster\& Ranta, 1997; Pica, 2002).

To examine negative feedback and its effects on oral production, considerable research of both empirical and descriptive nature has been conducted (e.g. Carrol \& Swain, 1993; Lightbown \& Spada, 1990; Lightbown, 1991; Herron \& Tomasello, 1988). One of the earliest descriptive studies was implemented by Chaudron (1977) who investigated the different CF kinds supplied to French immersion students by the teachers. He observed that while a great deal of CF went unnoticed, some types of CF (e.g, repetition with emphasis) led to more reformulations on the part of learners. Herron and Tomasello (1988) in their studies also suggested the beneficial impacts of certain CF techniques. Other studies including observation conducted by Lightbown and Spada (1990) and Lightbown (1991) also evidenced the constructive impacts of $\mathrm{CF}$ and focus on form. In a descriptive study with adults learners of French as a foreign language, Doughty (1994) also examined a variety of different CF types and found the most frequent CF were clarification requests, repetitions, and recasts. Another influential study, in this regard, was that of Russel and Spada (2004) which reviewed 56 papers on corrective feedback. They concluded that corrective feedback within focus on form instruction has a positive effect on learners' performance.

Other descriptive classroom researches (Havranek, 1999; Lochtman, 2000; Lyster \& Ranta, 1997; Panova\& Lyster, 2002) also investigated the interactional patterns of different CF types and their relationships to learners' uptake. Uptake is defined by Lyster and Ranta (1997) as "a student's utterance that immediately follows the teacher's feedback and that constitutes reaction in some way to the teacher's intention to draw attention to some aspect of the student's initial utterance."(1997, p.49). In fact, those studies in which uptake is used as a means of measuring learning show that it is an indication of learners' progress in learning language (Ellis, et al., 2001a; Loewen, 2005; Nassaji, 2009; Sheen, 2006). In this regard, a substantial body of research done on this issue shows the effectiveness of teachers' corrective feeback in triggering learners' uptake. A major study that has significantly contributed to investigating and examining corrective feedback and uptake in second language learning is that of Lyster and Ranta (1997) which studied the different CF types used by teachers to their learners while engaged in interactive based activities. The findings indicate that teachers mainly provide learners with CF types including: recasts, elicitation, metalinguistic feedback, clarification requests, corrective repetition, and explicit correction. 
This study indicated that among the different kinds of corrective feedback used by the teacher recasts were found to be the most frequent one (55\%) though not so effective to yield learner uptake and repair. Another finding was that the inefficiency of recasts was because of the recognition that students assumed that there is a focus on the content by the teacher rather than the linguistic form in their speech. Therefore, when hearing the teacher's reformulation, the learner did not figure out whether it was confirmation of his or her statement or a recast so in such a situation, the feedback was then of no use. In their own research, Macky and Philip (1998) also found that recasts might be effective for motivated adult learners in spite of the absence of any immediate response. In this respect, concerning the issue of recasts, in another study done in a young adult Iranian EFL context by Safari and Alavi (2013), recasts were found to be the type of CF frequently used by the teacher which led to the least amount of uptake. However, they found that when combined with other types of CF like elicitation or clarification requests, recasts could successfully elicit learner's immediate repair and uptake.

Taking explicit correction as another type of CF into account, Lyster and Ranta (1997) reported that $18 \%$ of the cases examined in the data were evidenced to be in the form of this CF type occurring in the flow of discourse for the respective context. However, this type of feedback technique failed to lead to the learner repair. Based on this study, the four other kinds (elicitation, clarification requests, metalinguistic feedback and repetition) were found to be the least frequently used ones but much more successful to elicit learner's uptake and to promote student-generated repair. In the case of explicit correction, a good ratio of uptake including correct student adjustments was observed. When the teacher preferred elicitation technique, it was always accompanied by the student's attempt to produce the accurate linguistic form themselves. In spite of a lower rate of uptake in the case of metalinguistic feedback, a similar ratio of the learner attempted reformulations was correct.

It is worth noting that Lyster and Ranta were meticulous to come to this conclusion that their study and the findings on $\mathrm{CF}$ as well as learner uptake yielded no definite assertions concerning the respective issue and that further studies were necessarily required to shed more light on this area. On the whole, it leaves no place for doubt that the research done by Lyster and Ranta (1997) is significant since the various kinds of error episode including teacher's use of corrective feedback, accompanying by learner's responses were meticulously taken into account. However, their research examined a variety of lessons and investigated discourse events in different classrooms representing immersion programs at the primary level. Thus, other studies in contexts different from that of Lyster and Ranta were necessary to gain more insights in this regard.

Another study concerning the issue of corrective feedback and uptake was carried out by Suzuki (2005). In his research, the discourse patterns of CF and uptake in adult ESL context were meticulously, described and analyzed. The findings indicated that there were differences to the findings gained from Lyster and Ranta's accounts (1997), although in some areas, similar results were examined. Based on this research, whereas the distribution of CF types pursuing errors committed by learners indicated little discrepancy from those gained by Lyster and Ranta's study, the proportion of learner uptake pursuing certain, to a great extent, varied from their findings. Some justifications were given to explain the differences in the results. These differences were mainly concerned to the characteristics of the classroom context such as learner's age, teacher's experience in addition to the target language.

Other studies also took carefully different variables into account to see how interactional patterns of feedback and uptake differ with respect to a particular variable. A research undertaken by Oliver (2000) showed that age was an important factor, which affected learners' attempts to repair errors. In this study, Oliver compared the differences between adult and child learners in responding to the corrective feedback and subsequent repairs occurring in communicative interactions in ESL lessons. The results showed that adult learners were more responsive to more corrective feedback than the child learners were. This researcher concluded that the reason for this difference seemed to be due to the children's limited level of social, psychological and cognitive development; the children might prefer simple feedback like recasts whereas the adults seemed to enjoy complex cognitive processing, such as confirmation and clarification request. Given this, while using corrective feedback in response to learners' errors, teachers should acknowledge learning contexts and learner variables (Ellis, Basturkmen, Loewen, 2001a; Loewen, 2004).

As it is clear, the main findings of studies concerning corrective feedback and uptake are primarily drawn from immersion classrooms; further research is however necessarily required to throw more light into the use of corrective feedback, uptake and immediate repair of errors following each type of feedback in different communicative EFL contexts. Thus, although a compelling body of research on corrective feedback and uptake has supported the crucial role of corrective feedback and learner's immediate repair of error, there are few researches which examine contextual and learner factors, such as, immersion/ESL class, learner's identity, age, motivation, previous learning experience and primary pedagogical focus which all have impacts on learners' uptake and research results (Ellis, et al., 2001a; Loewen, 2004). Accordingly, the present study attempts to determine the interactional discourse patterns of teacher's CF and learner's uptake taking place in an Iranian EFL context including adolescent learners. Hence, to achieve this goal, this study addresses the following questions:

1. What are the patterns of CF and uptake occurring in an Iranian EFL class with adolescent learners?

2. What kinds of CF are frequently examined in the class?

3. What kinds of CF yield the most learners' uptake and self-repair? 


\section{METhODOLOGY}

In order to address these questions, the researcher audio-taped, transcribed, coded and examined teacher- student interaction with respect to the types of corrective feedback, their frequency of use by the teacher in addition to the ratio of uptake pursuing them.

\section{A. Participants}

Teacher: A 38- year- old male teacher who had had the experience of teaching English in the Ministry of Education of Iran as well as different language institutes in Yazd and Shiraz, took part in this study. Currently, he was teaching English in Iranian schools in Kuwait. He held M.A degree in TEFL from Yazd University 8 years ago in advance of this study. Due to the presence of a great amount of interaction on the basis of observations between the teacher and the learners in addition to the teacher's fluency in handling discussion and interaction, this teacher and her class were selected for the present study.

Learners: 16 students of both genders aged between 13 to16 participated in the study. All of them lived in Kuwait but were native speakers of Persian studying English in a conversation class at the low-intermediate level.

\section{B. Data Collection}

Over a four-week period including 8 sessions, the whole data for the present study were collected. This Iranian EFL class was located in Kuwait, aimed at teaching English to 16 adolescent learners on the basis of Top Notch textbook authored by Saslow and Ascher (2006). The respective textbook was entirely communicative and interactional oriented, featuring meaning-focused activities and tasks, pair work, group work, discussion based activities, essential model conversations, strategies and activities promoting critical thinking and also authentic texts connecting students to the real world. In addition to the textbook, the teacher provided learners with some internet- based materials, because he felt that the reading texts of the book could not appropriately challenge the learners. Thus, in order to obtain data, all oral interactions between the teacher and learners were audiotaped during 8 sessions. As some parts of each session belonged to greeting, the provision of input, giving instruction, checking learners' homework and assigning homework for the pursuing session, the researcher ignored the respective data in the process of data analysis. In this study, the researcher did not intervene in the way the teacher controlled and conducted his class due to the fact that it was meant to be observational and descriptive. Therefore, neither the teacher nor the learners were conscious of the purpose of tape recording.

The researcher audiotaped and measured all the data including the amount of negative feedback used by the teacher as well as the patterns of learner uptake, self repair and topic continuation being in learners' utterances. The audiotaped teacher-learner interaction was then precisely transcribed and coded by the researcher assisted by a colleague. However, in order to achieve more reliable data, the researcher previously provided the colleague with the definitions of the coding categories. Then, after discussing the transcribed data with the colleague, the researcher ensured the removal of any incompatibility.

The main reason for involving the assistant in the respective study was to entertain the inter-rater reliability. In doing so, a random sample of the database was selected and then the assistant was separately required to code them with the result of $92 \%$ confirmity in the description and the recognition of the CF types and uptake categories. This percentage of reliability showed that inter-rater reliability was at a satisfactory level.

\section{Data Analysis}

In the present study, the coding definitions for the analysis of the data were based on Lyster and Ranta's CF model (1997). With respect to this model, each error treatment sequence (episode) includes the error made by a learner, a corrective feedback used by the teacher and learner's uptake in response to the CF. With respect to this model, the present study makes an attempt to pursue the relevant descriptions and categories. Figure1 vividly shows the various parts of an episode, based on Lyster and Ranta's feedback model. 


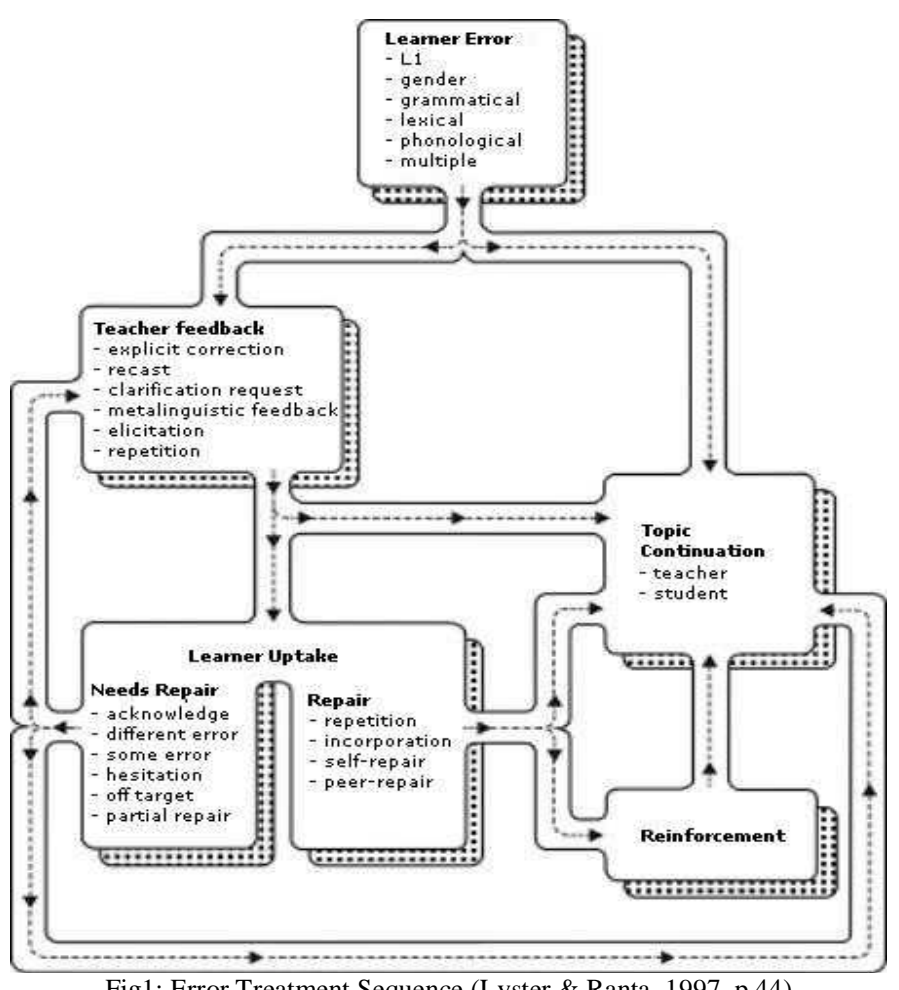

In the pursuing parts, we take carefully each component of this model into account:

Learner Error: According to this model, the different kinds of errors that are categorized include: phonological, lexical, grammatical and multiple. Based on Lyster and Ranta's model (1997), there was another category known as L1 unsolicited error in the case of those errors where learners resorted to the use of their L1 in the learner's error move. Although, in this study, all the learners had the same L1 background, there was no trace of this error type among the obtained data. Generally, all the different types of errors contained in this study were labeled as error. Thus, all the students' erroneous utterances to which the teacher provided CF were identified and computed, then the ratio of utterances including negative feedback could be determined.

Feedback: The teacher utilized six sorts of CF utilized when responding to the learners' errors. These are classified as the following (we should notice that in all sections, the researcher has used the examples taken from the recorded data of the respective communicative Iranian EFL context which were precisely transcribed and coded on the basis of the categories and descriptions identified in Lyster and Ranta's model of error treatment):

Explicit Correction: The teacher clearly indicates that the student's utterance is incorrect, so he or she provides the learner with the correct form of the erroneous utterance. Occasionally, the erroneous form is accompanied by the provision of a correct form in teacher's move.

S: But Nancy didn't stay and the Nancy came.

T: Nancy came not the Nancy.

S: Nancy came and they met Nancy.

Recasts: A kind of feedback technique in which the teacher implicitely reformulates all or parts of a student's illformed utterance minus the error (Lyster \& Ranta, 1997).In other words, the teacher provides the correct form as implicitly as possible.

$\mathrm{S}$ : His mother washes the dishes and clean the kitchen.

$\mathrm{T}$ : and she cleans the kitchen.

$\mathrm{S}$ : and she cook dinner.

Clarification Request: This feedback type carries questions showing the utterance has been ill-formed or misunderstood. Actually, it might be in two different forms including questions like parden? what? as well as sorry? or even the use of utterances with rising tone to show that the learner has committed the error. Unlike explicit correction and recasts, clarification request can be more consistently relied upon to elicit modified output from learners since it might not supply learners with any information concerning the sort and location of the error ( Rezaei, Mozaffari \& Hatef, 2011)

S: She know.

T: Sorry?

S: she knows.

S: she goes to school and play.

T: What? 
S: Plays football.

Metalinguistic Feedback: This contains either comments, information, or questions related to the well-formedness of the utterance, without explicitly providing the correct form. It points to the nature of error to elicit the information from the student (Lyster \& Ranta, 1997). Metalinguistic comments make the learner linguistically consider the error.

S: For his birthday, they bring things like: plates, glasses and rugs and none was special...

T. are you talking about present or past? So for past you should say brought him things like, ok?

S: I think they lived many years ago.

Elicitation: On the basis of Lyster and Ranta's model(1997), this refers to the techniques utilized by the teacher in order to directly elicit the right grammatical form from the learner. As an alternative technique, teachers might get learners to complete their own utterance through making a pause before the errounous part and then strategically give this chance to them to make the error correct. Another technique that teachers might apply is to use questions in order to have learners provide the corret form. In any case, teachers are not supposed to supply the right form in their move.

S: He has a long white beard.

T: He has...

S: He has long white beard.

Repetition: In this technique, the learner's erroneous form is repeated by the teacher in order to draw learner's attention to it. In so doing, teachers change their intonation to emphasize the error.

S: He never cleans his room.

T: He never clean?

S: yes, He never cleans his room.

Uptake Types

The definition of uptake that we adopted in the current study is also on the basis of Lyster and Ranta's definition of uptake. This term refers to a student's response immediately pursuing the corrective feedback used by the teacher and is also defined as "a reaction to the teacher's intention to draw attention to some aspect of the student's initial utterance" (Lyster\& Ranta, 1997, p.49).

Uptake is an evidence that shows the student's effort to react to the teacher's corrective feedback. Taking Lyster and Ranta's model into account, we can see that uptake moves are categorized into repair and needs-repair. Repair $\mathrm{s}$ are done by a learner to react to the CF used by the teacher, in fact when learners try to correct their errors, the uptake results in repair. Whereas in the case of needs-repair, no repair is seen in the learner's response or uptake, so that the utterance is still in need of repair. Thus, more teacher's CF might be supplied to elicit learner's self-repair or it might lead to topic continuation that might initiate by either the teacher or the learner. No uptake, as the third category, is used to refer to the cases where the learner neither responds nor reacts to the teacher's CF. It is then worth analyzing instances of no uptake, since it shows which type of $\mathrm{CF}$ is unlikely to be reacted or responded by the learner. If topic continuation is examined in those cases where there exists no uptake. In fact, the topic continuation might begin from the teacher or the student. This study uses four kinds of repair identified in Lyster and Ranta's model as the following: repetition, self-repair, peer-repair and incorporation. The pursuing instances show the above mentioned types of repairs.

Repetition: In this kind of repair, the student repeats the correct form of the utterance provided by the teacher's CF.

S: I'm believing. (error, grammatical)

T: I believe not I'm believing. (feedback, explicit correction)

S: I believe. (repair, repetition)

Self-repair: This repair is in fact the learner' self-correction, generated in reaction to the teacher's feedback when the corrective feedback involves no correct form.

S: They telling a story. (error, grammatical)

T: They telling? (feedback, repetition)

S: a story, they are telling a story. (repair, self-repair)

Peer-repair: It is also called the peer-correction supplied by another student other than the learner who committed the error.

S1: I'm tired about much work. He is a boy. (error, grammatical)

T: sorry, I'm tired about much work? (feedback, clarification request)

S2: tired of. (repair, peer-repair)

T: I'm tired of much work.

Incorporation: It refers to "a student's repetition of the correct form provided by the teacher, which is then incorporated into a longer utterance produced by the student" (Lyster\& Ranta, 1997)

$\mathrm{S}$ : while the youngest sister was, had. (error, lexical)

T. had. (feedback, recast)

S: had short. (repair, incorporation)

Needs-repair: is another type of uptake when the learner response to the teacher's CF results in the repair of the initial erroneous utterance. Based on Lyster and Ranta's model, there are six types of needs-repair which include: acknowledgment, same error, different error, off-target, hesitation and partial repair. 
Acknowledgment: It is used when the learner positively identifies the $\mathrm{CF}$, and s(he) generally prefers yes or yeah in his or her response, as if s(he) wanted to say, yes, it was what I meant to say.

S: She get ready. (error, grammatical)

T: she gets ready. (feedback, recast)

S: Yes. (needs-repair, acknowledgment)

Same error: This refers to the repetition of the error in the uptake move by the learner in reaction to the teacher's CF, but the same error is repeated in his or her turn.

$\mathrm{S}$ : He wanted come. (error, grammatical)

T: Sorry? (feedback, clarification request)

$\mathrm{S}$ : wanted come. (needs-repair, same error)

Different error: In response the teacher's CF, the learner makes neither any correction nor any repeation of the erroneous utterance but commits a different error.

S. Where is she come from? (lexical error)

$\mathrm{T}$ : what? (feedback, clarification request)

$\mathrm{S}$ : Oh, where is she comes from? (needs-repair, different error)

Off-target: This refers to when the learner's response is not to the original form including in the teacher's CF as if there were no feedback.

S: What does the weather like? (error, grammatical)

$\mathrm{T}$ : What is the weather like? (feedback, recast)

S: It's sunny. (needs-repair, off-target)

Partial repair: The learner provides the uptake but only some part of the original erroneous utterance is corrected.

S: I don't want...to take me. (error, grammatical)

T: Didn't want her to take me. (feedback, recast)

S: Didn't want to take me. (needs-repair, partial error)

\section{RESULTS}

Due to the focus of this research which intends to identify the patterns of corrective feedback and their effects on learner's uptake, the absolute number of errors generated by learners is not reported. Rather, the number of total turns, episodes including errors which lead to learner's uptake and immediate repair are meticulously taken into account. In this regard, a total of 308 student turns as well as 262 teacher turns were counted. Of the total turns, we computed 181 episodes each containing a trigger (error) produced by the learner, a CF move from the teacher and a learner's subsequent uptake in response to the $\mathrm{CF}$.

The number and the percentage of distribution of each feedback type were shown in table 1.

TABLE1.

DISTRIBUTION OF CF TYPES

\begin{tabular}{|l|l|l|}
\hline Feedback Types & Number & $\%$ \\
\hline Explicit correction & 5 & $2.76 \%$ \\
\hline Recast & 93 & $51.38 \%$ \\
\hline Clarification Request & 8 & $4.41 \%$ \\
\hline Metalinguistic feedback & 3 & $1.65 \%$ \\
\hline Elicitation & 39 & $21.54 \%$ \\
\hline Repetition & 33 & $18.23 \%$ \\
\hline
\end{tabular}

As it is vividly indicated in table1, recast is the most frequent type of teacher-generated feedback which is slightly over half $(51.38 \%)$ of the total CF types used by the teacher. This finding shows that the teacher more often prefers to use recasts in response to learners' errors. Elicitation and repetition are two other CF types which were also frequently utilized in such a context. In the case of other CF types including clarification request, explicit correction, and metalinguistic feedback, the low percentage of frequency of use is seen.

In table 2, the number and percentage of CF moves in relation to uptake are illustrated.

TABLE2.

NUMBER AND PERCENTAGE OF DISTRIBUTION 0F TEACHER'S CF AND LEARNER'S UPTAKE

\begin{tabular}{|l|l|l|l|l|}
\hline Feedback & Uptake & $\%$ & Topic continuation( No Uptake) & $\%$ \\
\hline Explicit correction $(\mathrm{n}=5)$ & 5 & $100 \%$ & 0 & $0.00 \%$ \\
\hline Recast $(\mathrm{n}=93)$ & 37 & $39.78 \%$ & 56 & $60.22 \%$ \\
\hline Clarification Request $(\mathrm{n}=8)$ & 8 & $100 \%$ & 0 & $0.00 \%$ \\
\hline Metalinguistic feedback $(\mathrm{n}=3)$ & 1 & $33.33 \%$ & 2 & $66.66 \%$ \\
\hline Elicitation $(\mathrm{n}=39)$ & 39 & $100 \%$ & 0 & $0.00 \%$ \\
\hline Repetition $(\mathrm{n}=33)$ & 31 & $93.93 \%$ & 2 & $6.07 \%$ \\
\hline
\end{tabular}

With regard to the data in table 2, recast is shown to be the most frequently used type of CF technique in this study which is successful at generating $39.78 \%$ of successful student's repair; whereas $60.22 \%$ of such moves is of no use to 
lead to any uptake. It means learners do not respond to $60.22 \%$ of teacher's CF in the form of recasts. As vividly shown, metalinguistic feedback is the CF type that occurred the least, eliciting the lowest rates of uptake (33.33\%). In the case of this CF type, $66.66 \%$ of teacher's feedback moves is likely to promote topic continuation. Clarification request, elicitation, repetition and explicit correction, as other feedback techniques, are successful at eliciting the highest amount of student immediate uptake; although in the case of clarification request and explicit correction, the low frequency of use is observed.

In this study, the different kinds of learner uptake were also identified. In Table3, the frequency and distribution of different types of uptake following teacher's CF are presented.

TABLE3.

FREQUENCY AND DISTRIBUTION OF DIFFERENT UPTAKE TYPES

\begin{tabular}{|l|l|l|}
\hline Repair & Needs Repair & \multicolumn{1}{|c|}{ No Uptake } \\
\hline a) Self repair $n=84$ & a) Acknowledgment $n=9$ & \\
b) Peer-repair $n=10$ & b) Same error $n=12$ & \\
c) Incorporation $n=3$ & c) Different error $n=5$ & \\
d) Repetition $n=12$ & d) Off target $n=14$ & \\
\hline Total : 109 & e) Partial error $n=6$ & Total: 26 \\
Percentage: $60.22 \%$ & Total: 46 & Percentage: $14.36 \%$ \\
\hline
\end{tabular}

As indicated in table 3, student-generated repair is successfully elicited by more than half of the corrective feedback techniques (60.22\%). Of the total feedback moves used in such a context, $25.41 \%$ leads to needs-repair. While just $16.94 \%$ of feedback turns was ineffective at eliciting learner uptake. In other words, students largely recognized teacher's feedback as corrective feedback so that they almost successfully reacted to it $86 \%$ of the time.

\section{DiSCUSSION AND CONCLUSION}

The goal of this study was to investigate, describe and identify different types of corrective feedback including learner uptake moves in error treatment sequences occurring in this adolescent EFL class. The researcher also revealed the frequency and distribution of the CF types in relation to learner uptake. In the respective communicative EFL context, the teacher made use of varied range of CF types rather than being dependent on one form of corrective feedback. In fact, in conformity with other studies, this study reveals that recast is the type of feedback which is mostly preferred by the teacher, though not so efficient to lead to the high rates of repair. The findings of the current study also show that those CF types that are much more effective in eliciting student-generated repair relatively rarely occur in the classroom. Based on this study, clarification request, elicitation, repetition and explicit correction which successfully lead to student-generated repair, are rarely used by the teacher. With respect to this finding, when teaching in such communicative EFL contexts including adolescents, teachers are required to provide learners with frequent rates of the respective $\mathrm{CF}$ types which yield the highest ratio of repair. In sum, teachers should avoid using the excessive amount of one technique, particularly when it is unsuccessful in leading to a satisfactory percentage of repairs, and should make an attempt to consciously consider other CF techniques in relation to different factors like various EFL contexts, learners' needs, level of language proficiency and age.

As another crucial finding, it was understood that the metalinguistic technique was ineffective at eliciting learner's uptake in this adolescent communicative EFL context. Based on this finding, teachers should behave cautiously while using the feedback techniques, keeping in mind the different factors embedded in each context such as learners' age. Since some CF types that yield learner repair seem to be appropriate for cognitively competent learners.

With respect to the findings concerning uptake directly following each feedback type, it is said that more than half of the feedback turns successfully leads to student-generated repair. This can be indicative of the fact that corrective feedback and uptake should constitute a common but crucial feature of a communicative discourse, since the flow of classroom communication is not only broken but also is learner's language accuracy effectively enhanced. If teachers take risks regularly embedding such corrective sequences, this intervention does not bring about any frustration in learners, so that they normally welcome such interactional interventions and accept them as the indispensable part in the context of language use. Thus, it is suggested teachers not choose between two alternatives including communication and corrective feedback, since both can be infused into the discourse interactions (Doughty \& Varela, 1998; Spada \& Lightbown, 1993).

The last but not least, it should be noted that the patterns of teacher's CF and learner uptake might fluctuate, dependent on the type of the EFL context of instruction in which they take place. Particularly, a variable such as learners' age triggers outcomes different from other EFL contexts including different variables. Based on this study, it is recommended that different findings be achieved relying on the different factors related to communicative contexts and learners. Thus, before taking any action for planning and applying corrective feedback techniques for language programs, we are required to meticulously take into account the type of the EFL context and the different embedded variables affecting interaction, the types of $\mathrm{CF}$, uptake, and repair. Furthermore, this study also offers insights for more studies to investigate the different variables which trigger discrepancies in the outcomes of CF patterns and uptake. 


\section{REFERENCES}

[1] Carrol, S. \& M. Swain. (1993). Explicit and implicit negative feedback. Studies in Second Language Acquisition 15, 357-386.

[2] Chaudron, C. (1977). A descriptive model of discourse in the corrective treatment of learner's errors. Language Learning 27, $29-46$.

[3] Doughty, C. (1994). Fine- tunning of feedback by competent speakers. In J. Alatis (ed.), strategic interaction and language acquisition: Theory, practice, and research. Washington, DC: Georgetown University Press, 96-108.

[4] Doughty, C. \& E. Varela. (1998). Communicative focus on form. In C. Doughty \& J. Williams (eds.), Focus on form in classroom second language acquisition. New York: Cambridge University Press, 114-138.

[5] Doughty, C. \& J. William. (1998). Pedagogical choices in focus on form. In C. Doughty, \& J. Williams (eds.), Focus on form in classroom second language acquisition. Cambridge: Cambridge University Press, 197-261.

[6] Ellis, R. (2001a). Investigating form-focused instruction. Language Learning 51.1, 1-46.

[7] Ellis, R. (2001b). Some thoughts on testing grammar: An SLA perspective. In C. Elder, A. Brown, E. Grove, K. Hill, N. Iwashita, T. McNamara \& K. O' Louglin (eds.), Experimenting in uncertainty: Essays in honour of Alan Davis. Cambridge: University Press, 251-263.

[8] Ellis, R. (2005). Principles of instructed language learning. System 33.2, 209-224.

[9] Ellis, R., H. Basturkmen \& S. Loewen. (2001a). Learner uptake in communicative ESL lessons. Language Learning 51.2, 281318.

[10] Ellis, R., H. Basturkmen \& S. Loewen. (2001b). Preemptive focus on form in the ESL classroom. TESOL Quarterly 35.3, 407432.

[11] Ellis, R., H. Basturkmen \& S. Loewen. (2002). Doing focus on form. System 30, 419-432.

[12] Faerch, C., \& Kasper, G. (1986). The role of comprehension in second language learning. Applied Linguistics, 7, $257-74$.

[13] Hatch, E. (1978). Acquisition of syntax in a second language. In J. Richards (ed.), Understanding second and foreign language learning. Rowley, MA: Newbury House, 34-70.

[14] Havranek, G. (1999). The effectiveness of corrective feedback: Preliminary results of an empirical study. Retrieved from http://www.uni-klu.ac.at/iaa/Department/gh_correction.htm. (accessed 5/12/2006).

[15] Herron, C. \& M. Tomasello. (1988). Learning grammatical structures in a foreign language: Modeling verses Feedback. The French Review 61, 910-922.

[16] Iwashita, N. (2003). Negative feedback and positive evidence in task-based interaction: Differential Effects on L2 Development. Studies in Second Language Acquisition 25, 1-36.

[17] Krashen, S. (1985). The input hypothesis: Issues and implications. Beverly Hills, CA: Laredo.

[18] Larsen-Freeman, D. \& M. H. Long. (1991). An introduction to second language acquisition research. Harlow: Longman.

[19] Leeman, J. (2003). Recasts and second language development. Studies in Second Language Acquisition 25, 37-63.

[20] Lightbown, P. M. (1991). What have we here? Some observations on the role of instruction in second language acquisition. In R. Phillipson, E. Kellerman, L. Selinker, M. Sharwood-Smith \& M. Swain (eds.), Foreign language pedagogy research: A commemorative volume for Claus Faerch. Clevedon: Multilingual Matters, 197-212.

[21] Lightbown, P. M. (2000). Classroom SLA research and second language teaching. Applied Linguistics 21. 4,431-62.

[22] Lightbown, P. \& N. Spada. (1990). Focus-on-form and corrective feedback in communicative language teaching: Effects on second language learning. Studies in Second Language Acquisition 12, 529-448.

[23] Lochtman, K. (2000). The role of negative feedback in experiential vs. analytical foreign language teaching. Paper presented at the conference on Instructed Second Language Learning. Brussels, Belgium.

[24] Loewen, S. (2004a). Uptake in incidental focus on form in meaning-focused ESL lessons. Language Learning 54, $153-188$.

[25] Loewen, S. (2004b). The occurrence and characteristics of student-initiated focus on form. In H. Reinders, H. Anderson, M. Hobbs \& J. Jones- Parry (eds.), Supporting independent learning in the $21^{\text {st }}$ century. Proceedings of the inaugural conference of the Independent Learning Association. Auckland: Independent Learning Association Oceania, 86-93.

[26] Loewen, S. (2005). Incidental focus on form and second language learning. Studies in Second Language Acquisition 27, $361-$ 386.

[27] Long, M. H. (1983). Negative speaker/ non-native speaker conversation and the negotiation of comprehensible input. Applied Linguistics 4, 126-141.

[28] Long, M. H. (1991). Focus on form: A design feature in language teaching methodology. In K. de Bot, R. Ginsberg \& C. Kramsch (eds.), Foreign language research in cross-cultural perspective. Amsterdam: John Benjamins, 39-52.

[29] Long, M. H. (1996). The role of linguistic environment in second language acquisition. In C. Ritchie \& T. K. Bhatia (eds.), A handbook of second language acquisition. New York: Academic Press, 413-468.

[30] Long, M. \& P. Robinson. (1998). Focus on form in classroom second language acquisition. In C. Doughty \& J. Williams (eds.), Focus on form: Theory, research and practice. Cambridge: Cambridge University Press, 15-41.

[31] Lyster, R. (1998a). Negotiation of form, recasts, and explicit correction in relation to error types and learner repair in immersion classrooms. Language Learning 48, 183-218.

[32] Lyster, R. (1998b). Recasts, repetition, and ambiguity in L2 classroom discourse. Studies in Second Language Acquisition 20, 51-81.

[33] Lyster, R. (2004). Differential effects of prompts and recasts in form-focused instruction. Studies in Second Language Acquisition 26, 399-432.

[34] Lyster, R. \& L. Ranta (1997). Corrective feedback and learner uptake: Negotiation of form in communicative classrooms. Studies in Second Language Acquisition 19, 37-66.

[35] Mackey, A. (1999). Input, interaction, and second language development. Studies in Second Language Acquisition 21, $557-587$.

[36] Mackey, A. \& J. Philip (1998). Conversational interaction and second language development: Recasts, responses and red herrings? The Modern Language Journal 82, 338-356. 
[37] McDonough, K. (2005). Identifying the impact of negative feedback and learners' responses on ESL question development. Studies in Second Language Acquisition 27, 79-123.

[38] Mclaughlin, B. (1987). Theories of second language acquisition. London: Edward Arnold.

[39] Oliver, R. (2000). Age differences in negotiation and feedback in classroom and pair work. Language Learning 50, 119-151.

[40] Nassaji, H. (2009). Effects of recasts and elicitations in dyadic interactions and the role of feedback expliciteness. Language Learning 59.2, 411-452.

[41] Oliver, R. \& A. Macky. (2003). Interactional context and feedback in child ESL classrooms. Modern Language Journal 87, 519-43.

[42] Panova, I. \& R. Lyster. (2002). Patterns of corrective feedback and uptake in an adult ESL classrooms. ESL Quarterly 36, 573595.

[43] Pica, T. (2002). Subject matter content: How does it assist the interactional and linguistic needs of classroom language learners? The Modern Language Journal 86, 1-19.

[44] Philip, J. (2003). Constraints on "noticing the gap": Nonnative speakers' noticing of recasts in NS-NNS interaction. Studies in Second Language Acquisition 25, 99-126.

[45] Rezaei, S., F. Mozaffari \& A. Hatef. (2011). Corrective Feedback in SLA: Classroom practice and future directions. International Journal of English Linguistics 11.1, 21-29.

[46] Russel, J. \& N. Spada (2004). The effectiveness of corrective feedback for second language acquisition. Toronto: University of Toronto.

[47] Safari, P. \& S.M. Alavi. (in press). On the relationship between recasts and learner's uptake: Evidence from a young adult EFL class. Iranian EFL Journal.

[48] Saslow, J. \& A. Ascher. (2006). Top Notch. English for today’s world. New York: Pearson Longman.

[49] Schmidt, R. (1990). The role of consciousness in second language learning. Applied Linguistics 11, 129-158.

[50] Schmidt, R. (1995). Consciousness and foreign language learning: A tutorial on the role of attention and awareness in learning. In R. Schmidt (ed.), Attention and awareness in foreign language learning. Honolulu: University of Hawaii Press, 1-63.

[51] Schmidt, R. (2001). Attention. In P. Robinson (ed.), Cognition and second language instruction. New York: Cambridge University Press, 3-32.

[52] Schmidt, R. \& S. Frota. (1986). Developing basic conversational ability in a second language: A case study of an adult learner of Portuguese. In R. Day (ed.), Talking to learn: Conversation in second language acquisition. Rowley, MA: Newbury House, 237-326.

[53] Sheen, Y. (2006). Exploring the relationship between characteristics of recasts and learner uptake. Language Teaching Research 10.4, 361-392.

[54] Spada, N., \& P. M. Lightbown. (1993). Instruction and the development of questions in L2 classrooms. Studies in Second Language Acquisition 15, 205-224.

[55] Suzuki, M. (2005). Corrective feedback and learner uptake in adult ESL classrooms. TESOL \& Applied Linguistics. Columbia: Columbia University Press.

[56] Surakka, K. (2007). Corrective feedback and learner uptake in an EFL classroom. Unpublished pro gradu thesis, University of Jyvaskyla.

[57] Swain, M. (1985a). Large-scale communicative language testing: A case study. In Y. P. Lee, et al. (eds.), New directions in language testing. Oxford: Pergamon Press, 35-46.

[58] Swain, M. (1985b). Communicative competence: Some roles of comprehensible input and comprehensible output in development. In S. Gass \& C. Madden (eds.), Input in second language acquisition. Oxford: Oxford University Press, 125-144.

[59] Swain, M. (1995). Three functions of output in second language learning. In G. Cook \& B. Seildlhofer (eds.), Principles and practice in applied linguistics: Studies in honor of H. G. Widdowson. Oxford: Oxford University Press, 125-144.

Parvin Safari received her B.A in TEFL from Shiraz University, Iran. She got M.A in the same major from Yazd University. As an English teacher, she is currently teaching in Iranian Schools in Kuwait. She has also authored several papers in different national and international journals. Her main interests are: critical pedagogy, teacher education, and discourse analysis. 